\title{
Effect of Human Capital on Employee Performance in Harta Insan Karimah Parahyangan Sharia Rural Bank
}

\author{
Puteri Andika Sari, Management Study Program, Ekuitas School of Business, Indonesia
}

\begin{abstract}
The role of human resources in an organization occupies an important position as human resources which can be a differentiating factor with another organization. Along with the development of human resources for the switches position as the capital of an organization so that can be a competitive force for an organization, or it's called human capital. The purpose of this study was to test the concept of human capital development on employee performance. Human capital development is influenced by several factors, such as training and development, level of education and knowledge. The collection of primary data obtained through a questionnaire that was allocated to the 40 employees Sharia Rural Bank HIK Parahyangan as respondents. The method used was Partial Least Square (PLS). Finding of this study revealed human capital has a significant positive effect on employee performance with a total contribution of $19.32 \%$, while the remaining $80.68 \%$ is influenced by other factors that are not observed in this study.
\end{abstract}

Keywords - human capital development, human resource management, employee performance.

\section{INTRODUCTION}

Cov OMPETITION in the era of globalization is characterized by the increasing number and diversity of ownership of the products of foreign companies that enter this country. Competition is also no exception to the rural banks (RB), which is in sight. This competition faced by the national banking microfinance-related small and medium enterprises (SMEs) as well as dealing with the implementation of the ASEAN Economic Community in 2015.

Nationally, the growth of RB in the first quarter of 2012 range from $22 \%$ year on year [1]. This indicates good prospects for the future. Along with the development time, the banking business is the principle of sharia won the trust of prospective customers. This occurs because of the assumption or perception of prospective customers or clients feel confident with the management of the bank. In addition to the many conventional banks have sharia business unit on the

Puteri A. Sari submitted the paper on June, $10^{\text {th }} 2015$ for review. This work was supported by Ekuitas School of Business (STIE Ekuitas), Jl. P.H.H Mustopa No.31 Bandung 40124, West Java, Indonesia.

Puteri A. Sari is with the Ekuitas School of Business (STIE Ekuitas), J1. P.H.H Mustopa No.31 Bandung 40124, West Java, Indonesia as a lecturer (email: puteri.andika31@ekuitas.ac.id/puteri.andika31@gmail.com). field; the RB was doing the same thing, known as Sharia Rural Banks (SRB).

Sharia Rural Bank Harta Insan Karimah (HIK) Parahyangan is one example of a sharia rural bank that is located on J1. Percobaan No. 1 Cileunyi, Bandung. SRB HIK Parahyangan per May 2010 achieved growth above 50\% both for Third Party Funds (TPF), and asset financing. Third Party Funds, in the period May 2010 reached Rp. 119, 59 billion increase compared to that in the period May 2009 which amounted to Rp. 76, 13 billion, with growth reaching $57.08 \%$, from the aspect of financing reached Rp. 122.50 billion is also increased when compared to the achievement in the period May 2009 which amounted to Rp. 78, 55 billion by the year 2010 was an increase of $55.95 \%$ in terms of assets later in the period May 2010 reached Rp. 139, 07 billion increase when compared to that in the period May 2009 which amounted to Rp. 91.79 billion with a growth increased 51.52\% [2]. Achievement of the performance above requires the creation of excellence product quality services produced by SRB HIK Parahyangan. The achievement of a superior product will be possible to achieve, if the management of human resources in the company well executed. Achievement of successful performance of SRB HIK Parahyangan not be separated from the performance of its human resources.

Under these conditions, the position of human resources becomes critical in an organization. The role of human resources in an organization occupies an important position as human resources can be a differentiating factor of an organization to another. Along with the development of human resources to switch its position as the capital for an organization so that it can be a competitive advantage for an organization, or the so-called human capital. Human capital development is influenced by several factors, such as training and development, level of education and knowledge. The development of human capital is expected to improve the performance of employees of a company.

Based on the background and formulation of the problem, the purpose of this study is to determine the influence of human capital on the performance of employees in the SRB HIK Parahyangan. 


\section{LITERATURE REVIEW}

\section{A. Human Capital}

Human element become the potential impact into the success of the organization, in fact, now organizations that want to compete and survive must consider human resources as a driver of competitive advantage in business. The ability of human capital to apply the science and knowledge into their work that makes a company has an advantage in competing. Tangible assets will experience the aging process as used to produce a product but not the case with the human capital. The only resource that has the ability to learn and grow is human resources. Therefore, through the empowerment of employees, human resources can be fully developed its potential to contribute to the optimum in producing a product.

Human capital describes each individual employee capabilities -which is brought and required- will lead to increased economic value added in all areas of the business, and can be considered as an investment for the organization. There are various definitions of human capital. In Table 1 below describes some experts about the definition of human capital [3].

TABLE I

DEFINITIONS OF HUMAN CAPITAL

\begin{tabular}{cl}
\hline Writers & \multicolumn{2}{c}{ Definition } \\
\hline Koulopowlos (1999) & $\begin{array}{l}\text { The accumulated value of the knowledge } \\
\text { available to the organization. }\end{array}$
\end{tabular}

OECD (1999)

Fitz-enz (2000)

Reinhardt (2001)

Schultz et al. (2002)

$\mathrm{Xu}$ et al. (2002)

Weatherly (2003)

Fernands et al. (2004)

Rauch et al. (2005)

Al-Ali et al. (2006)

Yaseen (2007)
Human capital includes knowledge, skills, and competencies embodied in individual employees and economic activity associated with them.

Human capital is the experience, knowledge, skills, and abilities that are owned by employees and used in the production process, which can be measured by training and development and incentive systems.

Total labor and their knowledge of the work consist of elements, such as: competence, skills, and attitudes towards work, the right answer and motivation.

Human capital is the knowledge, skills, skills of employees in providing solutions for customers.

Human capital includes knowledge, skills, and abilities of employees.

Total cumulative of the experience, position, knowledge and creativity, energy, and enthusiasm shown by the people to invest in his business.

Knowledge of the organization and stay in the minds of employees, and others who are outside the organization.

Included in human capital are a learning experience and the expertise of employees.

Overall experience and knowledge, ability, enthusiasm, creativity and quality are owned by the employees at an organization.

The combination of knowledge, learning, core competencies of the employees in order to achieve the objectives, the programs in the organization and their functional tasks.

Based on some definitions above, it can be concluded that human capital is the integration of knowledge, learning, experience, core competencies, skills, ability to be possessed by every employee that exist within an organization or company. So that, the most skilled human capital theory focuses on investments in certain types of education and the impact of return on investment from the intangible assets in human capital.

\section{B. Training and Development}

Training tends to be a key element in the development of human capital. Training employees contribute to the economic capital stock. Training is also very closely related to an innovation that will improve the skills of employees. Therefore, the development of human capital through training will complement these innovations [4].

Training is a process of teaching specific knowledge and skills and attitudes so that employees are more skilled and able to carry out their better responsibilities, according to the standard [5]. In other words, the company provides training to its employees to bridge the gap between the competences of their existing employees with the required competencies of the company.

It is not easy to say that after doing the training on the employee then began the development of the employee. The next step is to emphasize the long-term development and focus on developing the ability of the manager now or in the future. Development management is an attempt to improve performance management today or in the future by providing the knowledge, changing attitudes, or increasing skills. Development management process consists of [6]:

a) Assessing the needs of the company's strategic.

b) Assess the performance of current employees.

c) Develop employee (and aspiring managers).

\section{Education}

Nowadays, we are confronted with the information-based economy where technology and production methods change rapidly. Intangible capital and knowledge produces the best added value in addressing these changes and therefore the formation of human capital should be followed as well as the formation of physical capital (tangible). Education plays an important role in the formation of human capital [7].

Forming component of human capital, i.e. education background is a key quality of labor. Education contribute to the productivity of the two faces. Education can improve the quality and capabilities of the employees, the more productive use of their knowledge. Improving education tend to improve the level of intellectual development that will also add to existing knowledge [8].

Human capital theory emphasizes how education can improve the productivity and efficiency of workers through increased stock levels of human cognitive abilities economically which is a product of innate ability and human investment. The provision of formal education is seen as a productive investment in human capital, in which some human 
capital theory is that equal or even a higher level than the physical capital [9].

\section{Knowledge}

Knowledge capital has emerged as a competitive resource for the organization and human resource practitioners, human resource functions become single leadership potential role in the regulation of the organization today and in the future [10]. Significantly, human resource practitioners should be aware of the strategic importance of the recognition of human and knowledge capital in creating exemplary service and innovation. In the future, the practice of human resources of an organization will depend on their ability to align human capital and knowledge of key business strategies. Human resource management is the allocation of long-term strategic planning and human capital and knowledge that is aligned with key business strategies.

However, knowledge is not a business resource, but social resources that are universal. Anyone can access to the knowledge needed by various facilities (books, library, publications, the Internet). The factor that really makes an organization different from other companies is located on human capital capabilities in exploiting knowledge. Therefore, the determinants of long-term competitiveness of the organization lies in the ability of human resources in the use of the knowledge that they control to produce products and services that generate value for the customer [11].

The high demand in the competitive arena of knowledge capital and knowledge workers bring new consequences for practitioners of human resources, including training needs, development, and education for employees. The demand for knowledge workers and knowledge capital will lead to a change in the landscape of professional development of human resources [10]. The employees will need education in order to face the competition arena, business strategy, and their role in influencing the company's financial performance.

In the company, the knowledge used by the two parties following:

1. Employees; the knowledge used to produce products and services that generate value for the customer so that the knowledge becomes productive.

2. The management; knowledge is used to manage the organization so that the company is performing better [11].

\section{E. Employee Performance}

One key to the success of a company is depend on performance of human resources that directly or indirectly contribute to the company, which includes external stakeholders and internal purposes (employees) owned by the company. Optimum performance is obtained from the presence of employees in the company, and then the company needs to establish the right strategy, i.e. by thinking about how to manage employees to want to achieve the company's goals that have been set.

Performances is a work in quality, quantity, and timeliness is achieved by one's employees in carrying out their duties in accordance with the responsibilities assigned to him [12]. Performance is the result of a person or the overall success rate for a certain period in the task compared with a range of possibilities, such as the work standards, targets or goals or criteria are predetermined and agreed upon [13]. The performance is a set of results and refers to the act of achievement and the implementation of any work required [14]. Performance is a function of motivation and ability. To complete a task or job, one must have a degree of willingness and a certain level of ability [15].

Performance in an organization is a combination of all human resources in the organization, both leaders and workers. There are so many factors that affect human resources in running performance. There is a factor that comes from within the human resource itself (intrinsic) or from outside (extrinsic) [16]. The intrinsic elements are:
a) Level of education
b) Level of knowledge
c) Level of skill
d) The attitude-motivation to work
e) The level of work experience

While extrinsic elements including the following:
a) Family environment
b) Socio-cultural environment
c) Economic environment
d) Learning environment
e) Working environment including work culture
f) Technology

\section{PREVIOUS RESEARCH}

Here are some previous studies that support the creation of this hypothesis.

TABLE II

PREVOIUS RESEARCH

\begin{tabular}{|c|c|c|c|c|}
\hline No. & Writer & & Keywords & Result \\
\hline 1 & $\begin{array}{l}\text { Odit } \\
(2010)\end{array}$ & & $\begin{array}{l}\text { Human capital, } \\
\text { education, } \\
\text { economic growth }\end{array}$ & $\begin{array}{l}\text { Education possessed by } \\
\text { human capital is an } \\
\text { important factor in } \\
\text { influencing the level of } \\
\text { economic growth [17]. }\end{array}$ \\
\hline 2 & $\begin{array}{l}\text { Olaniyan } \\
\text { Okemakinde } \\
\text { (2008) }\end{array}$ & $\&$ & $\begin{array}{l}\text { Education, human } \\
\text { capital }\end{array}$ & $\begin{array}{l}\text { Investment in education } \\
\text { has a positive correlation } \\
\text { to the growth and } \\
\text { development of the } \\
\text { economy [9]. }\end{array}$ \\
\hline
\end{tabular}

\begin{tabular}{|c|c|c|c|}
\hline No. & Writer & Keywords & Result \\
\hline 1 & $\begin{array}{l}\text { Awang et al. } \\
(2010)\end{array}$ & $\begin{array}{l}\text { Training, } \\
\text { competency, work } \\
\text { performance, } \\
\text { employee's } \\
\text { quality. }\end{array}$ & $\begin{array}{l}\text { There is empirical } \\
\text { evidence that training } \\
\text { program can enhance the } \\
\text { knowledge, skills, and } \\
\text { work behavior of } \\
\text { employees. Variables } \\
\text { related to the performance } \\
\text { of the employee except } \\
\text { cognitive competence [18]. }\end{array}$ \\
\hline 2 & $\begin{array}{l}\text { Ming Au \& } \\
\text { Altman }(2007)\end{array}$ & $\begin{array}{l}\text { Training, human } \\
\text { capital }\end{array}$ & $\begin{array}{l}\text { Training is positively } \\
\text { related to investment in } \\
\text { human capital. Employees } \\
\text { who have sufficient skills }\end{array}$ \\
\hline
\end{tabular}


that will positively affect its human capital [19].

\begin{tabular}{|c|c|c|c|}
\hline No. & Writer & Keywords & Result \\
\hline 1 & $\begin{array}{l}\text { Madsen } \text { et al. } \\
\text { (2002) }\end{array}$ & $\begin{array}{l}\text { Human capital, } \\
\text { labor migration, } \\
\text { knowledge of } \\
\text { learning }\end{array}$ & $\begin{array}{l}\text { This paper empirically } \\
\text { examines the relationship } \\
\text { between the amount of } \\
\text { human capital flowing into } \\
\text { the company and the two } \\
\text { activities that underlie a } \\
\text { company producing } \\
\text { knowledge, variation or } \\
\text { alteration and knowledge } \\
\text { retention. The findings } \\
\text { suggest that the increased } \\
\text { reliance on past experience } \\
\text { reduces the delivery of a } \\
\text { number of human capitals } \\
\text { in the future. This effect is } \\
\text { moderated by self- } \\
\text { reinforcing cycle of human } \\
\text { capital inflow. The inflow } \\
\text { of human capital also } \\
\text { decreases when a company } \\
\text { has recently adopted a new } \\
\text { change in its operations } \\
\text { [20]. }\end{array}$ \\
\hline
\end{tabular}

\begin{tabular}{|c|c|c|c|}
\hline No. & Writer & $\begin{array}{l}\text { Keywords } \\
\end{array}$ & Result \\
\hline 1 & Endri (2010) & $\begin{array}{l}\text { Human capital, } \\
\text { human resource } \\
\text { management, } \\
\text { corporate } \\
\text { performance. }\end{array}$ & $\begin{array}{l}\text { This study literature } \\
\text { revealed relationship } \\
\text { between human capital and } \\
\text { corporate performance is a } \\
\text { reflection of the } \\
\text { performance of its } \\
\text { employees [21]. }\end{array}$ \\
\hline
\end{tabular}

\section{HYPOTHESES}

The hypotheses formulated in this research are as follows:

$\mathrm{H}_{1}$ : Education has a positive influence on the development of human capital.

$\mathrm{H}_{2}$ : Training and development has a positive influence on the development of human capital.

$\mathrm{H}_{3}$ : Knowledge has a positive effect on the development of human capital.

$\mathrm{H}_{4}$ : Human capital has a positive influence on employee performance.

\section{POPUlation AND SAMPlE}

The object of research as well populations was respondents of this study are the overall employees of SRB HIK Parahyangan. Sampling in this study was done by using disproportionate stratified random sampling. Furthermore, to establish the number of samples determined by using Slovin the opinion that:

Note:

$$
n=\frac{N}{1+N e^{2}}
$$

$\mathrm{n}=$ size of sample of the population

$\mathrm{N}=$ population size
$\mathrm{E}=$ the critical value (accuracy limit) desired (percent inaccuracy due to errors making the population), in this case $10 \%$.

The number of employees in SRB HIK Parahyangan as many as 70 people based on the results of the interviews. Thus, the sample size is 41 people, but the reality questionnaires were collected by 40 respondents.

The research data collected from observations, questionnaires, interviews, and a review of literature further analyzed using descriptive analysis and analysis of the research model using MINITAB 14. SmartPLS 2.0.M3 and MINITAB 14 are used to convert the data in the form of an ordinal scale questionnaire to intervals scale.

Descriptive analysis illustrates the proportion of respondents to a wide selection of answers that describe the factors that affect the capability of employees, which was moderated by the Human Capital practice through statement provided in the questionnaire.

\section{ANALYSIS OF PLS (PARTIAL LEAST SQUARE)}

In analyzing the effect of human capital on employee performance SRB HIK Parahyangan, used Partial Least Square (PLS). Structural equation modeling is a technique that can be used multiple variables to describe the interrelationship of linear simultaneous observation variables, which also involves a latent variable that cannot be measured directly.

The components used in the research model consisting of the variables include:

1. The latent variables are the key variables of concern because such an abstract concept (behavior, feelings, motivation, satisfaction, etc.). This variable can only be observed indirectly. Latent variables are of two types, namely: (a). Latent exogenous: independent variables with the symbol $\xi$; (b). Latent endogenous: the dependent variable by symbol $\eta$. In this study, the exogenous variables are training and development, education, and knowledge, while the endogenous variable is human capital and employee performance.

2. The observed variables or indicators. Are variables that can be observed or measured empirically? Mathematical notation for the observed variables which is a measure of the exogenous variables $(\xi)$ is $\mathrm{X}$, whereas the effect of endogenous latent variable is $\mathrm{Y}$.

\section{RESULT AND DisCUSSION}

\section{A. Model Specification}

This stage deals with the formation of the initial structural equation models, prior to estimation. This initial model was formulated based on a theory or previous research. The 


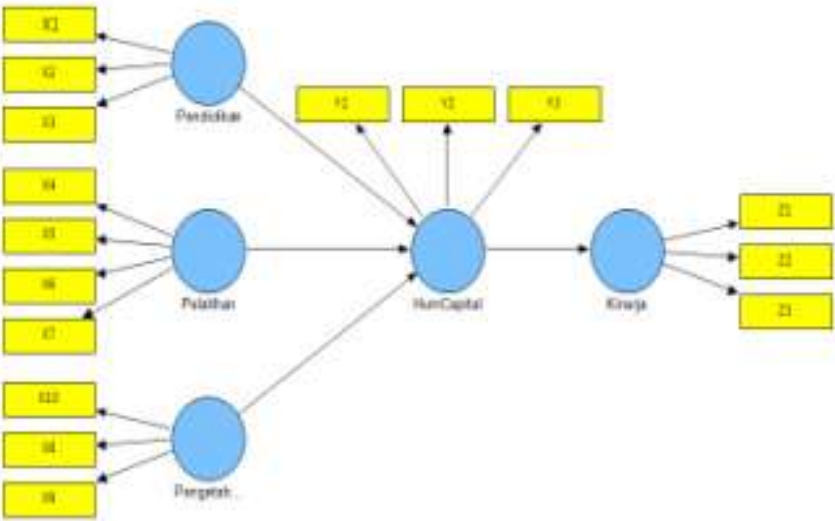

process of model estimation is done with the help of an application program SmartPLS 2.0.M3.

Fig. 1. The Conceptual Model of Partial Least Square Diagram

Through conceptual diagram above, it can be seen that the path model consists of two (2) sub-structures. In general, the two sub-structures can be described by the following equations:

Sub-structure 1:

Human Capital $=\mathrm{a}+\mathrm{b} 1+\mathrm{b} 2$ Education Knowledge Training

$+\mathrm{b} 3+\mathrm{e}$

Sub structure 2:

Performance $=\mathrm{a}+\mathrm{b} 4$ Human Capital $+\mathrm{e}$

\section{a. Outer Model}

Manifest variables in the study are as follows:

\section{- Education latent variable measured by three observed} variables, namely:

X1 : Education reflected by job title / position of the current employees.

X2 : Education suitability workload reflected by current employees.

X3 : Educational considerations are reflected by the current salary of the employee.

\section{- Training latent variable measured by four observed} variables, namely:

X4 : Training is reflected by the results of the training and learning from superiors.

X5 : The training is reflected by the discussions and learning from colleagues.

X6 : Training is reflected by the results of the feedback of the performance appraisal.

$\mathrm{X} 7$ : Training is reflected by the acquisition of specific skills certification.

- Knowledge of latent variable measured by three observed variables, namely:

X8 : Knowledge reflected by learning independently from other sources (books, internet, and literature).
X9 : A Knowledge employee to solve the problem is reflected by a discussion with co-workers during his spare time.

X10 : Knowledge of employees outside of work reflected by improvement suggestions insight and self-development (leadership, entrepreneurship, understanding customer psychology, and others).

\section{- Human Capital latent variable measured by three} observed variables, namely:

Y1 : Human capital is reflected by the employee in performing self-development.

Y2 : Human capital is reflected by the awareness of employees to undertake capacity building continuously (continuous improvement).

Y3 : Human capital is reflected by the making of a development plan for each individual organization and applies the learning organization.

- Performance latent variable measured by three observed variables, namely:

$\mathrm{Z} 1$ : Employee performance is reflected by the quantity of work that is influenced by education, training and knowledge of employees.

$\mathrm{Z} 2$ : Employee performance is reflected by the quality of the employees who are affected by education, training and knowledge of employees.

Z3: Employee performance is reflected by the timeliness of completing the work is influenced by education, training and knowledge of employees.

\section{b. Inner Model}

Human Capital variables are influenced by Education Variable, Training Variable and Knowledge Variable. Whereas the performance variable is affected by the variable human capital.

\section{B. Outer Evaluation Model}

This is the first stage of judging criteria for convergent validity. An indicator is said to have good validity if it has a loading factor value greater than 0.70 . Whereas loading factor of 0.50 to 0.60 can still be maintained for a model that is still in the development stage [22]. Based on estimates using the program application assistance SmartPLS 2.0.M3 obtained the following output. 


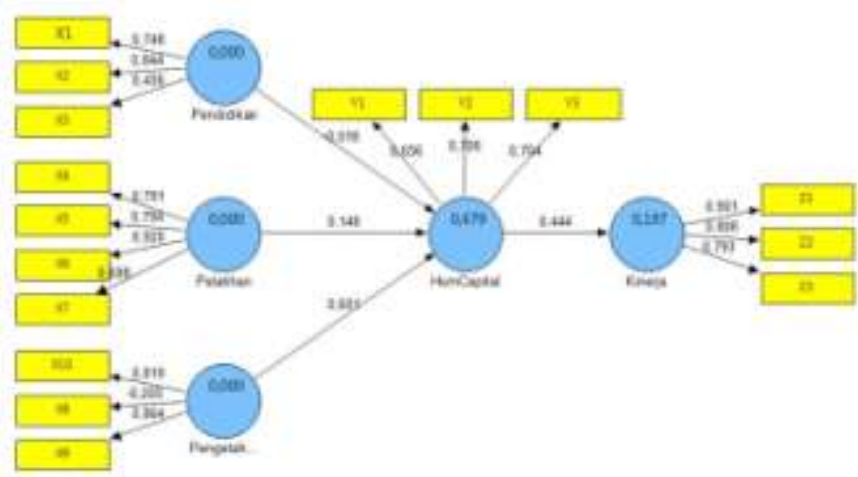

Fig. 2. Loading Value Factor Evaluation Model Banks

TABLE III

Cross Value Evaluation Outer Model Loading

\begin{tabular}{|c|c|c|c|c|c|}
\hline & $\begin{array}{c}\text { Human } \\
\text { Capital }\end{array}$ & $\begin{array}{c}\text { Perfor } \\
\text { mance }\end{array}$ & Training & Education & Knowledge \\
\hline $\mathbf{X 1}$ & 0,212 & 0,204 & 0,108 & 0,748 & 0,183 \\
\hline $\mathbf{X 2}$ & 0,264 & 0,501 & 0,475 & 0,844 & 0,482 \\
\hline $\mathbf{X 3}$ & $-0,002$ & 0,190 & 0,380 & 0,456 & 0,295 \\
\hline $\mathbf{X 4}$ & 0,402 & 0,317 & 0,791 & 0,307 & 0,403 \\
\hline $\mathbf{X 5}$ & 0,373 & 0,242 & 0,794 & 0,354 & 0,588 \\
\hline $\mathbf{X 6}$ & 0,415 & 0,463 & 0,920 & 0,358 & 0,558 \\
\hline $\mathbf{X 7}$ & 0,413 & 0,221 & 0,698 & 0,226 & 0,377 \\
\hline $\mathbf{X 8}$ & $-0,147$ & 0,038 & 0,099 & 0,147 & $-0,205$ \\
\hline $\mathbf{X 9}$ & 0,596 & 0,199 & 0,444 & 0,408 & 0,864 \\
\hline $\mathbf{X 1 0}$ & 0,550 & 0,220 & 0,629 & 0,384 & 0,819 \\
\hline Y1 & 0,656 & 0,406 & 0,328 & 0,125 & 0,448 \\
\hline Y2 & 0,706 & 0,227 & 0,322 & 0,059 & 0,377 \\
\hline Y3 & 0,704 & 0,263 & 0,378 & 0,397 & 0,558 \\
\hline $\mathbf{Z 1}$ & 0,399 & 0,901 & 0,349 & 0,474 & 0,255 \\
\hline $\mathbf{Z 2}$ & 0,331 & 0,808 & 0,181 & 0,299 & 0,128 \\
\hline $\mathbf{Z 3}$ & 0,377 & 0,793 & 0,429 & 0,366 & 0,195 \\
\hline
\end{tabular}

Based on Fig. 2 and Table 2 above, we see that all of the loading factor greater than 0.5 and only two indicators that have a factor loading value below 0.5, which is $\mathrm{X} 3$ and $\mathrm{X} 8$ indicators. Thus, the indicators are not valid are removed from the model, and then re-do the estimation. Re-estimation results can be seen through Fig. 3 and Table 4 below.

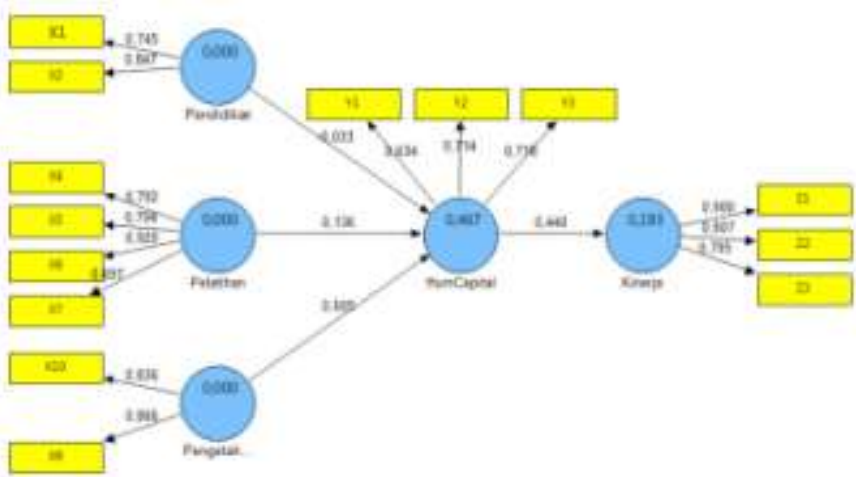

Fig. 3. Outer Value Evaluation Factor Loading After Re-Estimation Model Diagram

TABLE IV

Cross LoAdings Value Evaluation Outer AFter Re-ESTIMATION MODEL

\begin{tabular}{|c|c|c|c|c|c|}
\hline & $\begin{array}{c}\text { Human } \\
\text { Capital }\end{array}$ & Performance & Training & Education & Knowledge \\
\hline X1 & 0,212 & 0,204 & 0,108 & 0,745 & 0,203 \\
\hline X2 & 0,267 & 0,501 & 0,475 & 0,847 & 0,511 \\
\hline X4 & 0,406 & 0,318 & 0,792 & 0,309 & 0,421 \\
\hline $\mathbf{X 5}$ & 0,374 & 0,242 & 0,794 & 0,356 & 0,612 \\
\hline X6 & 0,412 & 0,464 & 0,920 & 0,361 & 0,579 \\
\hline X7 & 0,411 & 0,221 & 0,697 & 0,226 & 0,397 \\
\hline X9 & 0,601 & 0,199 & 0,444 & 0,409 & 0,866 \\
\hline $\mathbf{X 1 0}$ & 0,546 & 0,219 & 0,628 & 0,385 & 0,836 \\
\hline Y1 & 0,634 & 0,406 & 0,327 & 0,124 & 0,404 \\
\hline Y2 & 0,714 & 0,227 & 0,322 & 0,058 & 0,388 \\
\hline Y3 & 0,718 & 0,264 & 0,378 & 0,398 & 0,577 \\
\hline Z1 & 0,392 & 0,900 & 0,349 & 0,474 & 0,264 \\
\hline $\mathbf{Z 2}$ & 0,326 & 0,807 & 0,181 & 0,299 & 0,129 \\
\hline Z3 & 0,378 & 0,795 & 0,429 & 0,368 & 0,210 \\
\hline
\end{tabular}

Based on Fig. 3 and Table 4 above, it appears that after the re-estimation before issuing indicators invalid, the entire loading factor has been valued at over 0.5 . It can be concluded that the construct has good convergent validity. Value cross loadings also showed good discriminant validity because the value of the indicator correlation with the construct is higher than the value of the indicator correlation with other constructs [20]. 


\section{Analysis of Relationship Between Construct}

Once the model has been tested for their suitability then the next process is to analyze the relationship between the constructs or inner evaluation models. Analysis of the relationship between constructs is done by means of multiple regression analyzes (multiple regression). Through multiple regression analysis, we can know how significant relationship between the independent variables (exogenous) and dependent variable (endogenous).

The results provide conclusive evidence about the effect of information education, training and knowledge of the human capital and the effect of human capital on performance. Relationships between constructs can be said to have a value significantly if the T-Statistics is greater than 1.96. The estimation results of the relationship between constructs can be seen in Table 5 below.

TABLE V

Path COEFFicient VAlue

\begin{tabular}{|l|c|c|c|c|c|}
\hline & $\begin{array}{c}\text { Original } \\
\text { Sample } \\
(\mathbf{O})\end{array}$ & $\begin{array}{c}\text { Sample } \\
\text { Mean } \\
(\mathbf{M})\end{array}$ & $\begin{array}{c}\text { Standard } \\
\text { Deviation } \\
\text { (STDEV) }\end{array}$ & $\begin{array}{c}\text { Standard } \\
\text { Error } \\
\text { (STERR) }\end{array}$ & $\begin{array}{c}\text { T Statistics } \\
\text { (O/STERR) }\end{array}$ \\
\hline $\begin{array}{l}\text { Human } \\
\text { Capital -> } \\
\text { Performance }\end{array}$ & 0,440 & 0,444 & 0,051 & 0,051 & 8,542 \\
\hline $\begin{array}{l}\text { Training-> } \\
\text { Human } \\
\text { Capital }\end{array}$ & 0,136 & 0,141 & 0,067 & 0,067 & 2,033 \\
\hline & $\begin{array}{c}\text { Original } \\
\text { Sample } \\
(\mathbf{O})\end{array}$ & $\begin{array}{c}\text { Sample } \\
\text { Mean } \\
(\mathbf{M})\end{array}$ & $\begin{array}{c}\text { Standard } \\
\text { Deviation } \\
\text { (STDEV) }\end{array}$ & $\begin{array}{c}\text { Standard } \\
\text { Error } \\
\text { (STERR) }\end{array}$ & $\begin{array}{c}\text { T Statistics } \\
\text { (O/STERR) }\end{array}$ \\
\hline $\begin{array}{l}\text { Education -> } \\
\text { Human } \\
\text { Capital }\end{array}$ & $-0,033$ & $-0,029$ & 0,081 & 0,081 & 0,406 \\
\hline $\begin{array}{l}\text { Knowledge - } \\
\text { > Human } \\
\text { Capital }\end{array}$ & 0,605 & 0,602 & 0,075 & 0,075 & 8,109 \\
\hline
\end{tabular}

Based on Table 4 above it can be seen that there are some significant influence of exogenous variables on endogenous variables, as follows:

\section{a. Sub structure 1 (Model of Human Capital).}

- Effect of Education on Human Capital is not significant where the value of $t$ is smaller than the critical point $(0.406$ $<1.96$ ) with a path coefficient of -0.033 . This means that the presence or absence does not affect the educational dimension of human capital. The difference in these results due to the type of work that is in SRB HIK Parahyangan not require high levels of education because it basically requires a level of skill that is supported by the work experience, for example in the field of administrative work.

- Influence of Human Capital Training significant where the value of $t$ is greater than the critical point (2.033>1.96) with a path coefficient of 0.136 . Training tends to be a key element in the development of human capital. Traning contribute to the capital stock of the economy. Training is also very closely related to an innovation that will improve the skills of employees. Therefore, the development of human capital through training will complement these innovations.

- Knowledge of Human Capital Effect of significant where the $\mathrm{T}$ value is greater than the critical point $(8.109>1.96)$ with a path coefficient of 0.605 . The demand for knowledge workers and knowledge capital will lead to a change in the landscape of professional development of human resources. The employees will need education in order to face the competition arena, business strategy, and their role in influencing the company's financial performance.

\section{b. Sub structure 2 (Model Performance)}

- Influence of Human Capital to significant performance where the $\mathrm{T}$ value is greater than the critical point (8.542> 1.96) with a path coefficient of 0.440 . This proves that education, knowledge, and skills, which are an intrinsic factor, may be forming employee performance.

TABLE VI

PATH COEFFICIENT VALUE AND R-SQUARE VALUE

\begin{tabular}{|c|l|l|l|l|c|}
\hline \multirow{2}{*}{$\begin{array}{c}\text { Sub } \\
\text { Struct. }\end{array}$} & $\begin{array}{c}\text { Endogenous } \\
\text { variable }\end{array}$ & $\begin{array}{c}\text { Exogenous } \\
\text { Variable }\end{array}$ & $\begin{array}{c}\text { Path } \\
\text { Coef. }\end{array}$ & $\begin{array}{c}\boldsymbol{t} \text { - } \\
\text { statistic }\end{array}$ & $\begin{array}{c}\boldsymbol{R} \\
\text { Square }\end{array}$ \\
\hline \multirow{2}{*}{1} & \multirow{2}{*}{$\begin{array}{l}\text { Human } \\
\text { Capital }\end{array}$} & Training & 0,136 & 8,542 & \\
\cline { 3 - 5 } & Education & $-0,033$ & 2,033 & \multirow{2}{*}{0,4669} \\
\cline { 3 - 5 } $\begin{array}{c}\text { Sub } \\
\text { Struct. }\end{array}$ & $\begin{array}{c}\text { Endogenous } \\
\text { Variable }\end{array}$ & $\begin{array}{c}\text { Exogenous } \\
\text { Variable }\end{array}$ & $\begin{array}{c}\text { Path } \\
\text { Coef. }\end{array}$ & $\begin{array}{c}\boldsymbol{t} \text { - } \\
\text { statistic }\end{array}$ & $\begin{array}{c}\boldsymbol{R} \\
\text { Square }\end{array}$ \\
\hline 2 & Performance & $\begin{array}{c}\text { Human } \\
\text { Capital }\end{array}$ & 0,440 & 8,109 & 0,1932 \\
\hline
\end{tabular}

Through the above Table 6 , it can be seen that the Education, Training and Knowledge variables simultaneous effect of human capital variables of 0.4669 or $46.69 \%$, while the remaining $53.31 \%$ is influenced by other variables that are not observed in this study. Human Capital variables affect the performance variable of 0.1932 or $19.32 \%$, while the remaining $80.68 \%$ is influenced by other variables that are not observed in this study.

\section{CONCLUSION}

Based on the overall exposure analysis statistical calculations on the analysis of the path coefficients, coefficient of determination analysis and hypothesis testing, it can be concluded partially, Education, has no significant and negative effect on human capital, Training has a significant positive effect on human capital, and Knowledge has a significant and positive effect on human capital. Variable of education, training and knowledge contribute in shaping the human capital of $46.69 \%$, while the remaining $53.31 \%$ is influenced by other factors that are not observed in this study. Human capital has a significant positive effect on employee performance with a total contribution of $19.32 \%$, while the 
remaining $80.68 \%$ is influenced by other factors that are not observed in this study.

\section{REFERENCES}

[1] T. J. Tarigan. (2012, May). Persaingan BPR dengan Bank Umum Sudah Head to Head. [Online]. Available: http://jaringnews.com/politikperistiwa/interview/14475/t-jaya-tarigan-persaingan-bpr-dengan-bankumum-sudah-head-to-head.

[2] Hikparahyangan. co.id. Harta Insan Karimah Parahyangan Official Website. [Online]. Available: http://hikparahyangan.co.id/.

[3] I.A. Al-Ma'ani, M.S. Jaradat and Nasser. (2010). Impact of Human Capital on Organization Performance. Interdiciplinary Journal of Contemporary Research in Business. 2(4), pp. 63-73.

[4] J. Choudhury and B.B. Mishra (2010). Theoretical and Empirical Investigation of Impact of Developmental HR Configuration on Human Capital Management. International Business Research. 3(4), pp. 181-186.

[5] S. Mangkuprawira. (2004). Manajemen Sumber Daya Manusia Strategik. Jakarta: Ghalia Indonesia.

[6] G. Dessler. (2008). Human Resource Management. $11^{\text {th }}$ ed. New Jersey: Pearson Prentice Hall.

[7] 1. Nadrag and C.P. Mitran, (2011). Invest in People: A Way of Developing Human Resources. Economics, Management, and Financial Markets. 6(1), pp. 522-537.

[8] R. Hawlett. (2002). Integrating Human Capital Concepts in Productivity and Growth Topics. Journal of Management Research. 2(1), pp. 22-42.

[9] D.A. Olaniyan and T. Okemakinde. (2008). Human Capital Theory: Implications for Educational Development. European Journal of Scientific Research. 24 (2), pp. 157-162.

[10] J.K. Zula. The Development and Initial Assessment of an Instrument for Human Capital Planning. M.S. thesis, The Pennsylvania State Univ., Pennsylvania, USA, 2006.

[11] Mulyadi. (2007). Sistem Terpadu Pengelolaan Kinerja Personel Berbasis Balanced Scorecard. Yogyakarta: Sekolah Tinggi Ilmu Manajemen YKPN.

[12] A.P. Mangkunegara (2001). Manajemen Sumber Daya Manusia Perusahaan. Bandung: PT Remaja Rosdakarya.

[13] V. Rivai and A.F. Basri. (2005). Manajemen Sumber Daya Manusia untuk Perusahaan dari Teori ke Praktek. Jakarta: PT. Raja Grafindo Persada.

[14] H.D. Stolovich and E.J. Keeps. (1992). Handbook of Human Performance Technology A Comprehensive Guide for Analysis and Solving Performance Problems in Organizations. San Fransisco: Jprney-Bass Publisher.

[15] P. Hersey and K. Blanchard. (1992). Manajemen Perilaku Organisasi. Jakarta: Erlangga.

[16] S. Mangkuprawira and A. Vitayala. (2007). Manajemen Mutu. Jakarta: Ghalia Indonesia.

[17] P.M. Odit, K. Dookhan and S. Fauzel. (2010). The Impact of Education on Economic Growth: The Case of Mauritius. The International Business \& Economics Research Journal. 9(8), pp. 141-152.
[18] M.S. Awang, N. Iqbal and M. Waqas (2011). The Impact of Human Capital on Urban Poverty: The Case of Sargodha City. Journal of Sustainable Development. 4(1), pp. 143-150.

[19] A.K. Ming Au and Y. Altman. (2007). Employee Training Needs and Perceived Value of Training in The Pearl River Delta of China. Journal of European Industrial Training. 32(1), pp. 19-31.

[20] T.L. Madsen, E. Mosakowski and, S. Zaheer. (2002). The dynamics of Knowledge Flows: Human Capital Mobility, Knowledge Retention and Change. Journal of Knowledge Management. 6(2), pp. 164-176.

[21] Endri. (2010). Peran Human Capital Dalam Meningkatkan Kinerja Perusahaan: Suatu Tinjauan Teoritis dan Empiris. Jurnal Administrasi Bisnis. 6(2), pp. 179-190.

[22] I. Ghozali. (2008). Structural Equation Modeling Metode Alternatif dengan Partial Least Square (PLS), $2^{\text {nd }}$ ed . Semarang: Badan Penerbit Universitas Diponegoro. 